\title{
Community of crustacean larvae in Mon coastal water of Myanmar
}

\begin{abstract}
The study on biomass, distribution, occurrence, composition, abundance and diversity of crustacean larvae was conducted in estuarine water of Mon coastal area with the aim to get more effective data for fishery ecology aspects in this area. Crustacean larvae samples were collected from Ahlyat coastal water in the north, Setse coastal water in middle portion, and Sitaw coastal water in the south of Mon coastal water during the period of March 2017 to February 2018. A total of 4941 specimens of crustacean larvae under 8orders of class Crustacea were found in the study areas. Sitaw coastal water has the highest crustacean larval composition and abundance and also the highest average number per station. Setse coastal water and Ahlyat coastal water were the second and third ranks. Based on frequency of occurrence, decapod larvae were highest percentage followed by mysis protozoea and stomatopod larvae. This present study, the highest larval abundance in April followed by June and February, respectively. As for total biomass, decapod larvae were highest recorded and the lowest biomass was isopod larvae. The relationships between diversity, evenness and richness of crustacean larvae have not been difference due to positive condition of larval abundance in three sampling areas. Regarding to larval crustacean assemblage in Mon coastal water, based on a cluster analysis, it illustrated the patchy distribution of the majority of crustacean larvae because the stations appearing similarity in larval groups and their abundance tended to be located adjacent to each other.
\end{abstract}

Keywords: community, biomass, diversity, crustacean larvae, Mon coastal water
Volume 7 Issue 5 - 2018

\author{
Naung Naung Oo \\ Department of Marine Science, Mawlamyine University, \\ Myanmar
}

Correspondence: Naung Naung Oo, Assistant Lecturer, Department of Marine Science, Mawlamyine University, Myanmar, Email nawngnaungoomarine@gmail.com

Received: September 29, 2018 | Published: October 17, 2018

\section{Introduction}

The knowledge of reproductive biology and developmental patterns is a key issue in order to understand evolution, distribution and ecology of marine animals. Marine organisms display numerous reproductive strategies, from asexual to sexual. Animals with sexual strategy produce eggs which can be deposited in nets or directly on the bottom, kept attached to the parents, or be released as free moving particles to the pelagic environment. These eggs hatch as several types of larval form, whose duration is very variable among and within taxonomic groups, from hours to months, even years.

Crustacean is a world-wide sub-phylum of Arthropoda that includes crabs, shrimps, lobsters and barnacles. There are many larvae of crustacean and over 42000 species. Most crustaceans are dieceous and fertilization of the eggs is internal. The female is the usual brooder, carrying the eggs about on her abdominal appendages, which affords some protection for the eggs until they hatch into a larval form. The characteristic crustacean larvae is the nauplius. The rate of growth varies with different larvae and depends on the availability of food and the water temperature. While the larvae of most crustaceans are pelagic filter feeders. Crustaceans may pass through a number of larval and immature stages between hatching from their eggs and reaching their adult form. Each of the stages is separated by a moult, in which the hard exoskeleton is shed to allow the animal to grow. The larvae of crustaceans often bear little resemblance to the adult and there are still cases where it is not known what larvae will grow into what adults. This is especially true of crustaceans which live as benthic adults, but where the larvae are planktonic and therefore more easily caught.

In most cases, the larvae become part of planktonic communities, constituting, besides the aforementioned pelagic eggs, the so called meroplankton. Meroplankton is temporary component of zooplankton primarily made up from the early life stages of different organisms with sizes between $0.2-2 \mathrm{~mm}$, whose later developmental stages are not planktonic. The lack of information about these planktonic phases impede to get a complete view of the biology of the species. In addition, understanding the whole planktonic community dynamics is imperative for marine ecosystem. As holoplankton (organisms spending their whole life cycle in the plankton), meroplankton is an important component of the pelagic food webs, contributing to the transfer of the organic energy produced by phytoplankton or bacterial loops to higher trophic levels. ${ }^{1,2}$

From the single species point of view, despite meroplanktonic stages represent a relatively short period within the entire life cycle, they are crucial as they may determine the recruitment spatial dynamics and strength, and hence the whole dynamics of many marine species populations. Due to the existence of these planktonic early life stages, the majority of marine populations are considered demographically open, as they may be highly 'connected' through their larval dispersive phase. ${ }^{3,4}$ Changes in dispersion patterns induced by differences hydrodynamic scenarios can result in important variations in the number of recruits arriving to a given area. Recruitment variability has fisheries implications, since it partly explains some of the interannual population abundance fluctuations at local scales observed in some species (eg. spiny lobster). ${ }^{5}$ On the other hand, interannual recruitment variability is also the result of larval survival rates along the planktonic phase resulting from the environmental factors affecting larval mortality rate. Larval development plays an important role in ecology, biogeography and evolution of marine organisms. ${ }^{6}$ 
The various authors studied the morphotaxonomy and biodiversity of holoplankton and meroplankton along the various localities of Myanmar coastal region by Kyi Win 7 , Kyi Win et al., ${ }^{7-14}$, Saw Han Shein ${ }^{15}$, Aung Kyi ${ }^{16}$, Kyi Win ${ }^{12}$, Gayder Kittim $\mathrm{Ku}^{17}$, Maung Maung Myint $^{18}$, Htay Htay Mon ${ }^{19}$, Win Win $\mathrm{Nwe}^{20}$, Zin Lin Khine and Htay Aung ${ }^{21}$, Htay Htay $\mathrm{Mon}^{22}$, Aye Mi San ${ }^{23}$, Nyo Nyo $\mathrm{San}^{24}$, Naung Naung $\mathrm{Oo}^{25}$, Aung Aung Htaik ${ }^{26}$, Zin Lin Khine ${ }^{27}$, Nyan Moe Naing ${ }^{28}$, Saw Tin Shwe ${ }^{29}$ and War War Nwe ${ }^{30}$. The purpose of this study is to elucidate the distribution, occurrence, composition, abundance and to know the biomass and diversity of crustacean larvae of Mon coastal water.

\section{Materials and methods}

Study area: The southeastern portion of the central deltaic area comprises the coast of Mon state (Figure 1). Here, the Thanlwin River opens into the Gulf of Martaban and Bilukyun (Giant Island) lies at its mouth. Mon coastal area is located between (Lat. $15^{\circ} 10^{\prime} \mathrm{N}$ and $17^{\circ} 30^{\prime} \mathrm{N}$; Long. $96^{\circ} 46^{\prime} \mathrm{E}$ and $98^{\circ} 15^{\prime} \mathrm{E}$ ) with a unique ecosystem which extends $320 \mathrm{~km}$ from the mouth of Sittaung River in the north to Kyungyi Island, Ye Township in the south. The samples were collected from Ahlyat (Lat. 16 $6^{\circ} 37^{\prime}$ N, Long. $97^{\circ} 27^{\prime}$ 'E) at Paung Township, Setse (Lat. $15^{\circ} 52^{\prime}$ N, Long. $97^{\circ} 34^{\prime}$ E) at Thanbyuzayat Township and Sitaw (Lat. $15^{\circ} 11^{\prime}$ N, Long. $97^{\circ} 48^{\prime}$ E) at Ye Township in Mon coastal water.

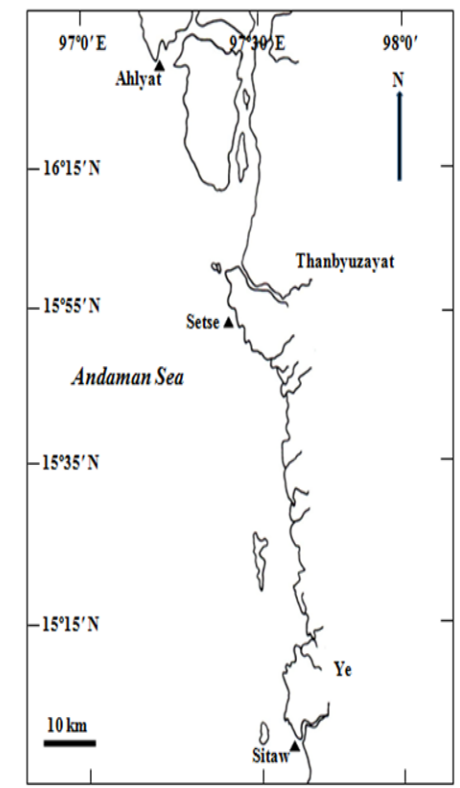

Figure I Map showing the sampling sites of crustacean larvae in Mon coastal water.

Observation of crustacean larvae in the field: In this study, crustacean larvae were collected from March 2017 to February 2018. The samples which are the basic material of this study were taken only from the surface water to a depth of about $2 \mathrm{~m}$. The standard plankton net was used in this study, which has the mesh size of $200 \mu \mathrm{m}$. The net was made of nylon monofilament. At the study area, because of the high and low tide conditions, qualitative collection were done twice each time by towing the net for a period of 5 minutes through the surface water. In this present study, oblique and vertical tows were made bimonthly throughout the larval collections. In each collection, debris and other materials were roughly sorted out from the planktonic samples. After collection the larval samples were preserved in $4 \%$ buffered formaldehyde solution diluted with seawater ${ }^{31}$, these samples were retained in $100 \mathrm{ml}$ white polyethylene bottles.

Analysis of samples in the laboratory: The total planktonic fauna were sorted in a petri disc at the laboratory by the help of a binocular microscope. Preserved larvae were taken one at a time on a clean glass slide and the lengths were measured by the help of an ocular micrometer. The important characteristics of planktonic larvae were photographed using a Sanyo VPC-T 1060 digital camera under compound microscope. The result assembled from digital photographs are processed by Adobe Photoshop 7.0.

Determination the species' frequency of occurrence $(F)$ : It is calculated taking into account the number of samples in which the organism was found, relative to the total number of samples collected, in percent. ${ }^{32} \mathrm{~F}=\mathrm{Ts} .100 / \mathrm{TS}$

Where: Ts=the number of samples in which the taxon (species) is present, and TS=the total number of samples. The results are presented in percentage (\%), being used the following approach: $>70 \%=$ Much Frequent; $70 \%-40 \%=$ Frequent; $40 \%-10 \%=$ Less Frequent and $<$ $10 \%=$ Infrequent/Sporadic.

Determination of the diversity index: The Shannon-Wiener Diversity Index $\left(\mathrm{H}^{\prime}\right)$ was used to describe the diversity of taxa collected. This diversity index has two properties: (1) $\mathrm{H}^{\prime}=0$ if and only if there is one species in a sample, and (2) $\mathrm{H}^{\prime}$ is maximum only when all species are represented by the same number of individuals, that is, a perfectly even distribution of abundance. Diversity Index $\left(\mathrm{H}^{\prime}\right)$ for determined the number of individuals of each species in the study areas, Species Evenness $\left(\mathrm{J}^{\prime}\right)$ for measured the relative abundance of the various population present in the study areas and Species Richness $\left(R^{\prime}\right)$ for measured the number of different species present in the study areas were also calculated by using the Shannon-Wiener Index, ${ }^{33}$ Pielou's ${ }^{34}$ and Margalef' ${ }^{35}$ These formulae are as follow:

$$
H^{\prime}=-\Sigma(P i \ln P i), J=H^{\prime} / \ln S, R^{\prime}=S-1 / \ln \mathrm{N}
$$

where $\mathrm{H}^{\prime}=$ Shannon-Wiener diversity index, $\mathrm{Pi}=$ the proportional abundance of the species $(\mathrm{ni} / \mathrm{N}), \mathrm{ni}=$ the no. of individuals of the species, $\mathrm{N}=$ the total no. of individuals of the species, $\mathrm{S}=$ number of species, $\mathrm{n}=$ the total number of individuals of given species.

Determination of biomass: The volume of crustacean larvae collected was estimated by settlement volume method. The samples are allowed to settle for at least 24 hours before recording the settled volume. After that, the fish larvae are sorted and measurement of body length and counting were made and then they were preserved in clean small bottles with formaldehyde solution. For biomass study, the samples were thoroughly stirred with a glass rod and an aliquot subsample of $2 \mathrm{ml}$ was taken, examined and counted under the microscope with small magnification. The process was repeated for five times, that is, a total of five aliquot subsample $10 \mathrm{ml}$ in volume was taken and the number of crustacean larvae counted.

Determination of community similarity: As with binary similarity coefficient analysis, binary occurrence or non-occurrence of each data set used to compare in the form of community similarity by using the Sorensen similarity index $(\mathrm{Ss}){ }^{36}$

$$
\mathrm{Ss}=2 \mathrm{C} / \mathrm{A}+\mathrm{B}
$$

Where: $\mathrm{C}=$ the number of species the two communities have in common, $\mathrm{A}=$ the total number of species found in the community $1, \mathrm{~B}=$ the total number of species found in the community 2 . For 
comparing the community structures of crustacean larvae by station, a cluster analysis was used as shown in the form of a dendrogram The analysis used Sorensen coefficients of similarity and followed the average linkage method.

\section{Results}

\section{Types of crustacean larvae in Mon coastal water}

Surveys of crustacean larvae diversity are increasingly being used to monitor the spawning areas and stock status of commercially important species. These surveys have contributed to improve the knowledge of the ecological relations among the communities, based on the analysis of the species distribution, occurrence, composition, abundance and its time and space variability.

There were eight important larval group of crustacean were identified in these study areas and all of them found at brackish water in epipelagic layer (Table 1). The distribution and occurrence variation of total crustacean larvae in Mon coastal water were shown in Table 2. A total of 4941 specimens of crustacean larvae consisted of 8orders were found in the study areas. Sitaw coastal water has the richest crustacean larval composition and abundance and also the highest average number per station (Table 3) (Figure 2). Setse coastal water and Ahlyat coastal water were the second and third ranks, respectively.

Table I Classification group of crustacean larvae in Mon coastal water

Crustacean larval group
Copepoda Milne-Edwards, 1840
(Nauplius larva of copepod)
Cirripedia Burmeister, 1834
(Nauplius larva of barnacle, Cypris larva of barnacle)
Ostracoda Latreille, 1802
(Pyrocypris larva of ostracod)
Mysidacea Haworth, I 825
(Protozoea larva of mysis)
Amphipoda Latreille, 1816
(Amphipod larva)
Isopoda Latreille, 1817
(Isopod larva)
Stomatopoda Latreille, 1817
(Squilla erichthus larva, Squilla alima larva, Lysiosquilla
larva)
Decapoda Latreille, I802
(Porcellana zoea, Lucifer protozoea, Caridean larva,
Acetes protozoea, Penaeus nauplius, Penaeus protozoea,
Brachyuran zoea, Brachyuran megalopa)

Among the collected larvae, 18group of crustacean larvae such as nauplius larva of copepods, nauplius and cypris larva of barnacle, pyrocypris larva of ostracod, protozoea larva of mysis, amphipod larva, isopod larva, Squilla erichthus and alima larva, Lysiosquilla larva, porcellana zoea, Lucifer protozoea, Caridean larva, Acetes protozoea, Penaeus nauplius, Penaeus protozoea, brachyuran zoea and brachyuran megalopa were obtained in all three sampling sites of Mon coastal water. The larval development of crustaceans in study areas described as a sequence of morphologically distinct stages. Among the principal criteria for the classification of larval forms and developmental patterns, the functional morphology of feeding appendages is of utmost importance.
Table 2 Distribution and occurrence of crustacean larvae in Mon coastal water

Symbols: $\mathrm{I}=$ present; $0=$ absent

\section{Sampling period}

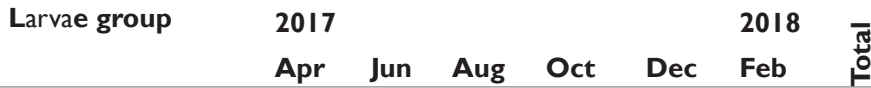

Ahlyat

Barn and cypris

Ostracod

pyrocypris

Mysis protozoea

Amphipod larva

Isopod larva

Stomatopod larva

Decapod larva

Total

Setse

\begin{tabular}{|c|c|c|c|c|c|c|c|}
\hline Copepod nauplius & I & 0 & 0 & 0 & I & I & 3 \\
\hline $\begin{array}{l}\text { Barnacle nauplius } \\
\text { and cypris }\end{array}$ & 1 & 1 & 0 & 0 & 1 & I & 4 \\
\hline $\begin{array}{l}\text { Ostracod } \\
\text { pyrocypris }\end{array}$ & 1 & 0 & 0 & 0 & 0 & I & 2 \\
\hline Mysis protozoea & 1 & I & I & I & 1 & 0 & 5 \\
\hline Amphipod larva & 0 & I & 0 & 0 & 0 & I & 2 \\
\hline Isopod larva & 0 & I & I & 0 & 0 & 0 & 2 \\
\hline Stomatopod larva & 1 & I & 0 & 1 & 1 & 0 & 4 \\
\hline Decapod larva & I & I & I & 1 & 1 & I & 6 \\
\hline Total & 6 & 6 & 3 & 3 & 5 & 5 & 28 \\
\hline \multicolumn{8}{|l|}{ Sitaw } \\
\hline Copepod nauplius & I & I & 0 & 1 & 0 & 0 & 3 \\
\hline $\begin{array}{l}\text { Barnacle nauplius } \\
\text { and cypris }\end{array}$ & 1 & 0 & 1 & 0 & I & I & 4 \\
\hline $\begin{array}{l}\text { Ostracod } \\
\text { pyrocypris }\end{array}$ & I & I & 0 & 1 & 0 & I & 4 \\
\hline Mysis protozoea & I & I & I & 1 & 1 & 0 & 5 \\
\hline Amphipod larva & 1 & 0 & I & 0 & 1 & I & 4 \\
\hline Isopod larva & I & I & I & 0 & 1 & 0 & 4 \\
\hline Stomatopod larva & 1 & I & I & 1 & 0 & I & 5 \\
\hline Decapod larva & I & I & 1 & 1 & 1 & I & 6 \\
\hline Total & 8 & 6 & 6 & 5 & 5 & 5 & 35 \\
\hline
\end{tabular}


Table 3 Composition and abundance of crustacean larvae in Mon coastal water

\begin{tabular}{|c|c|c|c|c|c|c|c|}
\hline \multirow{3}{*}{ Larvae group } & \multicolumn{7}{|c|}{ Sampling period } \\
\hline & \multicolumn{5}{|c|}{2017} & \multicolumn{2}{|l|}{2018} \\
\hline & Apr & Jun & Aug & Oct & Dec & Feb & $\stackrel{0}{\circ}$ \\
\hline \multicolumn{8}{|l|}{ Ahlyat } \\
\hline Copepod nauplius & 95 & 84 & 0 & 0 & 0 & 0 & 179 \\
\hline Barnacle nauplius and cypris & 68 & 0 & 0 & 0 & 65 & 33 & 166 \\
\hline Ostracod pyrocypris & 25 & 70 & 0 & 63 & 0 & 0 & 158 \\
\hline Mysis protozoea & 0 & 68 & 25 & 59 & 12 & 0 & 164 \\
\hline Amphipod larva & 45 & 0 & 0 & 0 & 0 & 89 & 134 \\
\hline Isopod larva & 23 & 35 & 23 & 0 & 0 & 0 & 81 \\
\hline Stomatopod larva & 0 & 56 & 99 & 44 & 0 & 0 & 199 \\
\hline Decapod larva & 0 & 31 & 80 & 19 & 33 & 51 & 214 \\
\hline Subtotal & 256 & 344 & 227 & 185 & 110 & 173 & 1295 \\
\hline \multicolumn{8}{|l|}{ Setse } \\
\hline Copepod nauplius & 64 & 0 & 0 & 0 & 59 & 72 & 195 \\
\hline Barnacle nauplius and cypris & 87 & 62 & 0 & 0 & 27 & 83 & 259 \\
\hline Ostracod pyrocypris & 46 & 0 & 0 & 0 & 0 & 65 & 111 \\
\hline Mysis protozoea & 51 & 38 & 90 & 13 & 26 & 0 & 218 \\
\hline Amphipod larva & 0 & 56 & 0 & 0 & 0 & 83 & 139 \\
\hline Isopod larva & 0 & 28 & 51 & 0 & 0 & 0 & 79 \\
\hline Stomatopod larva & 18 & 30 & 0 & 53 & 31 & 0 & 132 \\
\hline Decapod larva & 36 & 25 & 12 & 46 & 49 & 42 & 210 \\
\hline Subtotal & 302 & 239 & 153 & 112 & 192 & 345 & 1343 \\
\hline \multicolumn{8}{|l|}{ Sitaw } \\
\hline Copepod nauplius & 71 & 26 & 0 & 98 & 0 & 0 & 195 \\
\hline Barnacle nauplius and cypris & 35 & 0 & 93 & 0 & 83 & 67 & 278 \\
\hline Ostracod pyrocypris & 55 & 45 & 0 & 96 & 0 & 73 & 269 \\
\hline Mysis protozoea & 70 & 71 & 58 & 97 & 66 & 0 & 362 \\
\hline Amphipod larva & 37 & 0 & 39 & 0 & 98 & 52 & 226 \\
\hline Isopod larva & 18 & 49 & 82 & 0 & 19 & 0 & 168 \\
\hline Stomatopod larva & 82 & 88 & 84 & 37 & 0 & 97 & 388 \\
\hline Decapod larva & 67 & 24 & 89 & 76 & 90 & 71 & 417 \\
\hline Subtotal & 435 & 303 & 445 & 404 & 356 & 360 & 2303 \\
\hline Total & 993 & 886 & 825 & 701 & 658 & 878 & 4941 \\
\hline
\end{tabular}

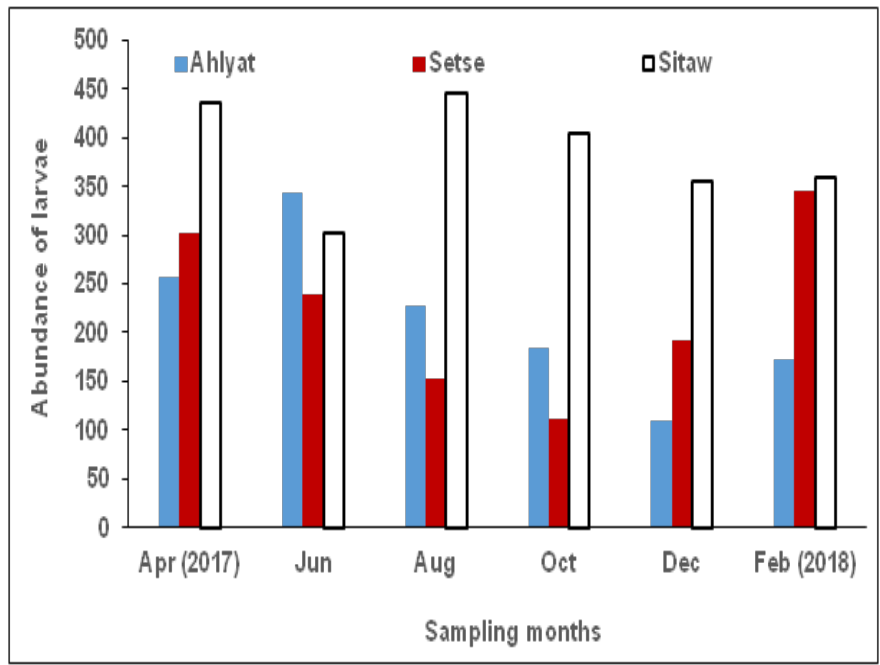

Figure 2 Composition and abundance of crustacean larvae in Mon coastal water.

\section{Biomass and diversity of crustacean larvae in Mon coastal water}

A total of 4,941 specimens of crustacean larvae consisted of 8 orders were found in the study areas. Sitaw station $\left(2303 / \mathrm{m}^{3}\right)$ was the richest crustacean larval composition and abundance and also the highest average number per station (Table $2 \& 3$ ) (Figure 2). Setse $\left(1343 / \mathrm{m}^{3}\right)$ and Ahlyat $\left(1295 / \mathrm{m}^{3}\right)$ stations were the second and third ranks, respectively. During the study period of March 2017 to February 2018, the crustacean biomass ranged between $2.466 \mathrm{ml} /$ $\mathrm{m}^{3}$ (decapod larvae) and $1.253 \mathrm{ml} / \mathrm{m}^{3}$ (isopod larvae) (Table 4). The ranged of standard deviation of crustacean larvae in Mon coastal water was $9.24 \pm 132.76$ (copepod nauplius \pm stomatopod larvae). Larval diversities of crustacean ranged between 1.098 and 1.000 for species diversity $\left(\mathrm{H}^{\prime}\right), 0.999$ and 0.909 for species evenness $\left(\mathrm{J}^{\prime}\right)$, and 0.345 and 0.297 for species richness $\left(\mathrm{R}^{\prime}\right)$ (Table 4) (Figure 3). According to the species frequency of occurrence, the most frequent species were decapod larvae $(94.44 \%)$ followed by mysis protozoea $(77.78 \%)$ and stomatopod larvae $(66.67 \%)$. The least frequency of occurrence was copepod nauplius and amphipod larva (44.44\%) (Table 4). 
Table 4 Quantitative analysis of crustacean larvae in Mon coastal water

Symbols: (1): >70\%=Much Frequent; (2): 70\%-40\%=Frequent; (3): 40\%- $10 \%=$ Less Frequent; (4)<10\%=Infrequent/Sporadic.

\begin{tabular}{|c|c|c|c|c|c|c|c|c|c|c|c|c|c|}
\hline \multirow{2}{*}{ Larvae group } & \multirow[b]{2}{*}{ 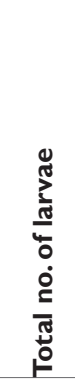 } & \multirow[b]{2}{*}{ 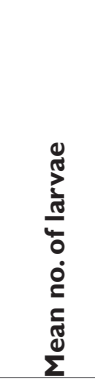 } & \multirow[b]{2}{*}{ 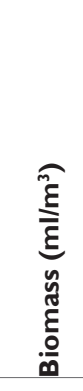 } & \multirow{2}{*}{ 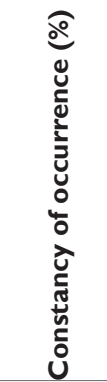 } & \multicolumn{4}{|c|}{ Diversity } & \multirow{2}{*}{ 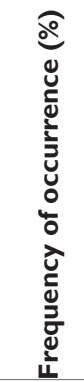 } & \multicolumn{4}{|c|}{$\begin{array}{l}\text { Classification according } \\
\text { to species' frequency of } \\
\text { occurrence }\end{array}$} \\
\hline & & & & & 只 & $H^{\prime}$ & $J$ & $R^{\prime}$ & & 1 & 2 & 3 & 4 \\
\hline \multicolumn{14}{|c|}{ March (20I7) - February (20 I8) } \\
\hline Copepod nauplius & 569 & 189.67 & 1.608 & 11.52 & 9.24 & 1.098 & 0.999 & 0.315 & 44.44 & & * & & \\
\hline $\begin{array}{l}\text { Barnacle nauplius and } \\
\text { cypris }\end{array}$ & 703 & 234.33 & 1.812 & 14.23 & 59.94 & 1.076 & 0.979 & 0.305 & 61.11 & & $*$ & & \\
\hline Ostracod pyrocypris & 538 & 179.33 & 1.305 & 10.89 & 81.13 & 1.032 & 0.939 & 0.318 & 50.00 & & $*$ & & \\
\hline Mysis protozoea & 744 & 248.00 & 1.948 & 15.06 & 102.35 & 1.043 & 0.949 & 0.302 & 77.78 & $*$ & & & \\
\hline Amphipod larva & 499 & 166.33 & 1.461 & 10.09 & 51.73 & 1.068 & 0.972 & 0.322 & 44.44 & & $*$ & & \\
\hline Isopod larva & 328 & 109.33 & 1.253 & 6.64 & 50.82 & 1.031 & 0.938 & 0.345 & 50.00 & & $*$ & & \\
\hline Stomatopod larva & 719 & 239.67 & 1.847 & 14.55 & 132.76 & 1.000 & 0.909 & 0.304 & 66.67 & & $*$ & & \\
\hline Decapod larva & 841 & 280.33 & 2.466 & 17.02 & 118.37 & 1.043 & 0.949 & 0.297 & 94.44 & $*$ & & & \\
\hline Total & $494 I$ & & & 100.00 & & & & & & & & & \\
\hline
\end{tabular}

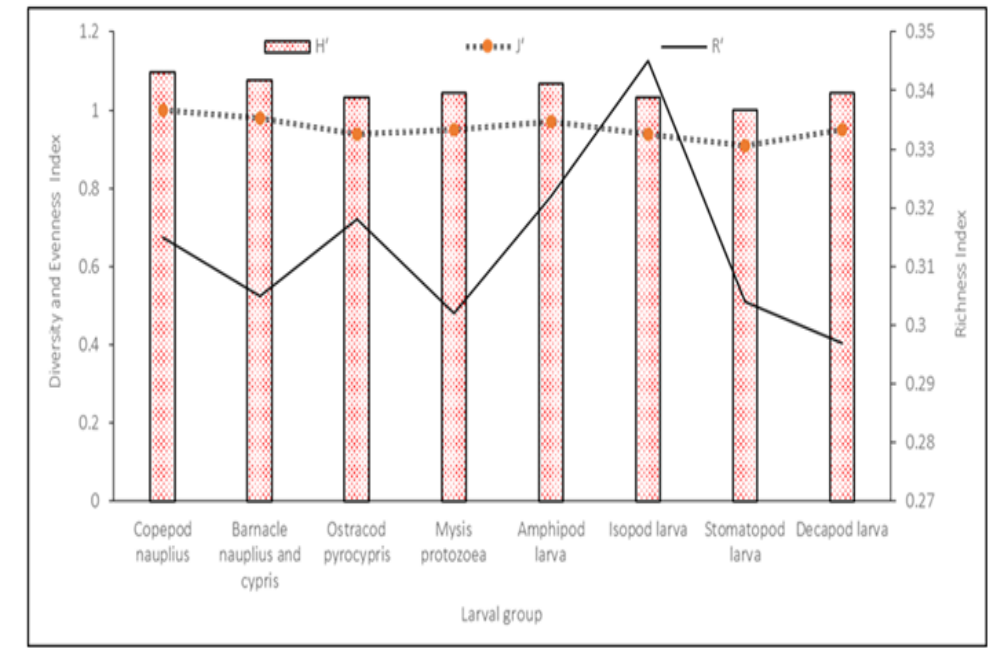

Figure 3 Diversity of crustacean larvae in Mon coastal water.

Ahlyat station: Decapod $\left(214 / \mathrm{m}^{3}\right)$ were the most abundant larvae of total crustacean larvae but isopod larvae $\left(81 / \mathrm{m}^{3}\right)$ were the least abundance of this station. The highest and lowest monthly abundance of crustacean larvae were $\left(344 / \mathrm{m}^{3}\right)$ in June and $\left(110 / \mathrm{m}^{3}\right)$ in December The highest composition of crustacean larvae in Ahlyat station was copepod nauplius $\left(95 / \mathrm{m}^{3}\right.$ in April), barnacle nauplius and cypris (68/ $\mathrm{m}^{3}$ in April), ostracod pyrocypris $\left(70 / \mathrm{m}^{3}\right.$ in June), mysis protozoea $\left(68 / \mathrm{m}^{3}\right.$ in June), amphipod larva $\left(89 / \mathrm{m}^{3}\right.$ in February), isopod larva
(35/ $\mathrm{m}^{3}$ in June), stomatopod larva $\left(99 / \mathrm{m}^{3}\right.$ in August) and decapod larva $\left(80 / \mathrm{m}^{3}\right.$ in August).

Setse station: In this station, the most abundant larvae were barnacle nauplius and cypris $\left(259 / \mathrm{m}^{3}\right)$ and the lowest abundant were isopod larva $\left(79 / \mathrm{m}^{3}\right)$. The highest and lowest monthly abundance of crustacean larvae were $\left(345 / \mathrm{m}^{3}\right)$ in February and $\left(112 / \mathrm{m}^{3}\right)$ in October. The highest composition of crustacean larvae in Setse station was 
copepod nauplius ( $72 / \mathrm{m}^{3}$ in February), barnacle nauplius and cypris ( $87 / \mathrm{m}^{3}$ in April), ostracod pyrocypris $\left(65 / \mathrm{m}^{3}\right.$ in February), mysis protozoea $\left(90 / \mathrm{m}^{3}\right.$ in August), amphipod larva $\left(83 / \mathrm{m}^{3}\right.$ in February),

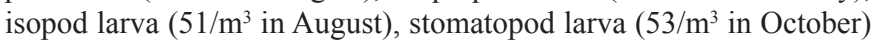
and decapod larva $\left(49 / \mathrm{m}^{3}\right.$ in December).
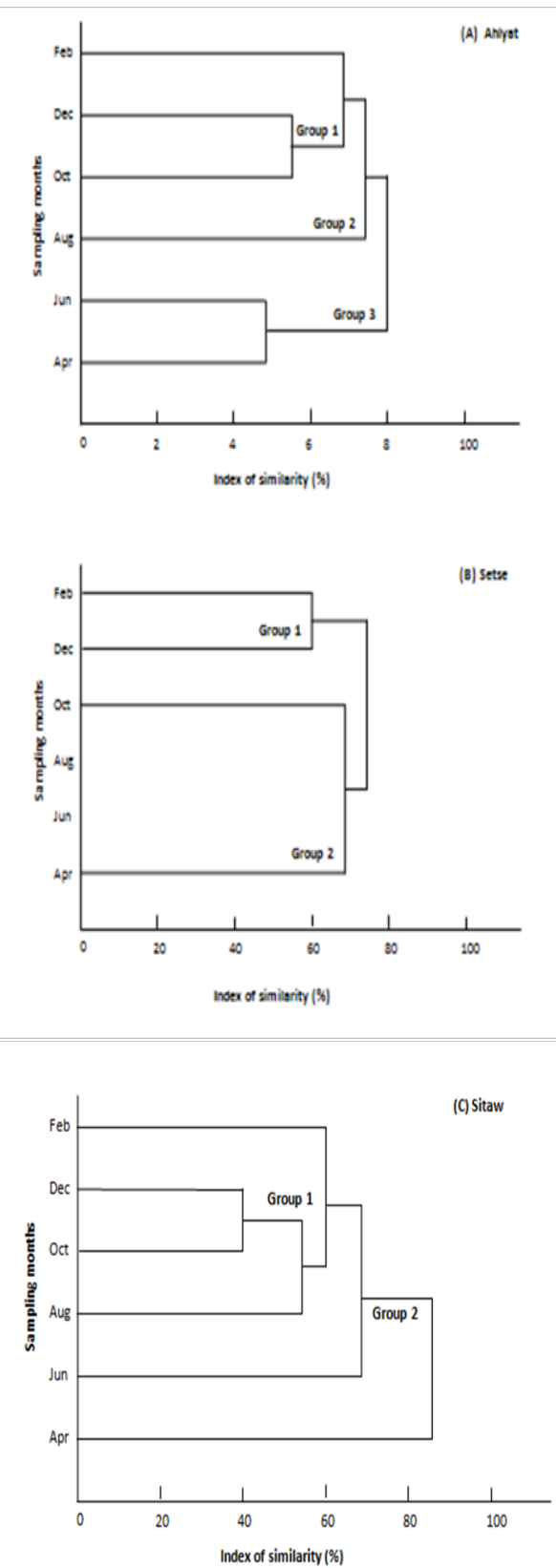

Figure 4 A-C. Dendrogram for cluster analysis of crustacean larvae in Mon coastal water during the study period of March 2017 - February 2018.

Sitaw station: In all three sampling stations, Sitaw was the most abundant and larval diversity. Decapod $\left(417 / \mathrm{m}^{3}\right)$ were the most abundant larvae of total crustacean larvae but isopod larvae (168/ $\mathrm{m}^{3}$ ) were the least abundance of this station. The highest and lowest monthly abundance of crustacean larvae were $\left(445 / \mathrm{m}^{3}\right)$ in August and $\left(303 / \mathrm{m}^{3}\right)$ in June. The highest composition of crustacean larvae in Sitaw station was copepod nauplius $\left(98 / \mathrm{m}^{3}\right.$ in October), barnacle nauplius and cypris $\left(93 / \mathrm{m}^{3}\right.$ in August), ostracod pyrocypris $\left(96 / \mathrm{m}^{3}\right.$ in October), mysis protozoea $\left(97 / \mathrm{m}^{3}\right.$ in October), amphipod larva $\left(98 / \mathrm{m}^{3}\right.$ in December), isopod larva ( $82 / \mathrm{m}^{3}$ in August), stomatopod larva (97/ $\mathrm{m}^{3}$ in February) and decapod larva $\left(90 / \mathrm{m}^{3}\right.$ in December).

\section{Community structure of crustacean larvae in Mon coastal water}

Classification of crustacean larvae assemblage by bimonthly in March 2017 to February 2018 using dendrogram was shown in Figure $4 \mathrm{~A}-4 \mathrm{C}$. The similarity cluster indicated the presence of 1-3 major groups based on larval number in species with roughly similar abundance and constructed with 3-5 clades and 6 leaves. The binary similarity coefficient analysis of Sorensen similarity index (Ss) values comparing species composition between sampling months were recorded and they ranged from 22 (minimum similarity at August, October and February) to 90 (maximum similarity at October and December) (Table 5).

a. Ahlyat station: Classification of crustacean larval assemblage by Ahlyat station using dendrogram was shown in Figure 4A. The similarity cluster indicated the presence of three major groups based on larval number in order groups with roughly similar abundance. The first group was characterized by two months which were October-December $\left(185 / \mathrm{m}^{3}-110 / \mathrm{m}^{3}\right)$ and December-February $\left(110 / \mathrm{m}^{3}-173 / \mathrm{m}^{3}\right)$. They were similar sharing of the second group August-October $\left(227 / \mathrm{m}^{3}-185 /\right.$ $\left.\mathrm{m}^{3}\right)$. The third group consisted of sampling month April-June $\left(256 / \mathrm{m}^{3}-344 / \mathrm{m}^{3}\right)$. This group was shared by group 2 and 1 , respectively.

b. Setse station: The similarity cluster analysis indicated the presence of 2 groups in this area (Figure $4 \mathrm{~B}$ ). The first group was characterized by 2 months, December-February (192/m³ $-345 /$ $\mathrm{m}^{3}$ ). The second group consisted of 4 sampling months, April

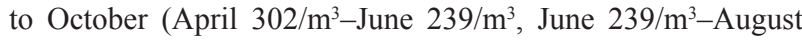
$153 / \mathrm{m}^{3}$ and August $153 / \mathrm{m}^{3}$-October $112 / \mathrm{m}^{3}$ ) were sharing of group 1 . The binary similarity coefficient analysis of Sorensen similarity index (Ss) values in group 2 were similar composition and abundance.

c. Sitaw station: The dendrogram classification of crustacean larvae assemblage was shown in figure 4C. The first group was 4leaves which distinguished August-October $\left(445 / \mathrm{m}^{3}-404 / \mathrm{m}^{3}\right)$, October-December $\left(404 / \mathrm{m}^{3}-356 / \mathrm{m}^{3}\right)$ and December-February $\left(356 / \mathrm{m}^{3}-360 / \mathrm{m}^{3}\right)$ in which August was the most abundant and followed by April, the second abundant sampling month. The second group was characterized by 3 months, April-June $\left(435 / \mathrm{m}^{3}-303 / \mathrm{m}^{3}\right)$ and June-August $\left(303 / \mathrm{m}^{3}-445 / \mathrm{m}^{3}\right)$, where 2 comprised groups, respectively.

Table 5 Similarity coefficient between sampling months based on occurrence of crustacean larvae in Mon coastal water

\begin{tabular}{lllllll}
\hline Ahlyat & Apr & Jun & Aug & Oct & Dec & Feb \\
\hline Apr & 100 & 54 & 22 & 22 & 25 & 50 \\
Jun & & 100 & 80 & 80 & 44 & 22 \\
Aug & & & 100 & 75 & 57 & 28 \\
Oct & & & & 100 & 57 & 28 \\
Dec & & & & & 100 & 66 \\
Feb & & & & & & 100 \\
Setse & Apr & Jun & Aug & Oct & Dec & Feb \\
Apr & 100 & 66 & 44 & 66 & 90 & 72 \\
Jun & & 100 & 66 & 66 & 72 & 54 \\
Aug & & & 100 & 66 & 50 & 25 \\
Oct & & & & 100 & 75 & 28
\end{tabular}


Table Continued.

\begin{tabular}{lllllll} 
Dec & & & & & 100 & 60 \\
Feb & & & & & & 100 \\
Sitaw & Apr & Jun & Aug & Oct & Dec & Feb \\
Apr & 100 & 85 & 85 & 76 & 76 & 76 \\
Jun & & 100 & 66 & 90 & 54 & 54 \\
Aug & & & 100 & 54 & 90 & 72 \\
Oct & & & & 100 & 40 & 60 \\
Dec & & & & & 100 & 60 \\
\hline Feb & & & & & & 100
\end{tabular}

\section{Discussion}

The biomass, species community and diversity of crustacean larvae were recorded from Ahlyat, Setse and Sitaw in Mon coastal water during the study period of March 2017 to February 2018. The shallow water shelf of Mon coastal estuaries were typically characterized by larvae of estuary-resident species in the copepod nauplius, barnacles nauplius and cypris, ostracod pyrocypris, mysis protozoea, amphipod larva, isopod larva, stomatopod larvae of alima, erichthus and Lysiosquilla larva, decapod larvae of Porcellana zoea, Lucifer protozoea, Caridean larva, Acetes protozoea, Penaeus nauplius and protozoea, and brachyuran zoea and megalopa (Table 1).

The total crustacean larvae of 8orders group found in this present study seem to be lower diversity than the former works that conducted in more productive area of the other part of Myanmar coastal water. Kyi $\mathrm{Win}^{12}$ reported the total of 310 warm water zooplankton and 67 planktonic larvae in Myanmar water. Moreover, a total of 12species of zooplankton larvae of some invertebrates from Myanmar Shelf Waters of Northern Andaman Sea during the pre-monsoon of 2002 (Win Win Nwe), ${ }^{20} 7$ species of zooplankton larvae from Myanmar Territory Waters of North-east Andaman Sea (Zin Lin Khine and Htay Aung) ${ }^{21} 25$ species of meroplanktonic larvae from Gulf of Matarban and its adjacent water (Htay Htay Mon), ${ }^{22} 18$ species of planktonic larval stages from Karoppi water (Aye Mi San) ${ }^{23}$ and 25 species of planktonic larvae from Kalagoke Island coastal water (Nyo Nyo San), ${ }^{24} 60$ taxa of zooplanktonic larvae from Damin tidal creek of Setse (Naung Naung Oo), ${ }^{25} 5$ species of planktonic larvae from Setse water (Aung Aung Htike), ${ }^{26}$ 6species of planktonic larvae from water mass off Taninthayi coast (Zin Lin Khine) ${ }^{27} 33$ species of planktonic larvae from Ka Byar Wa coastal water (Nyan Moe Naing) ${ }^{28} 28$ species of planktonic larvae from Ye River Mouth (Saw Tin Shwe) ${ }^{29}$ and 15 species of planktonic larvae from Taninthayi coastal water (War War Nwe $)^{30}$ have been studied from various coastal water of Myanmar.

In this study, during the study period, Sitaw coastal water was found to be the richest crustacean larval abundance (2303larvae $/ \mathrm{m}^{3}$ ) followed by Setse coastal water (1343larvae $/ \mathrm{m}^{3}$ ) and Ahlyat coastal water (1295larvae $\left./ \mathrm{m}^{3}\right)$. Although, the highest abundance of crustacean larvae was also found in Sitaw but it was not so much different comparing to 1343 and 1295larvae $/ \mathrm{m}^{3}$ that found in Setse and Ahlyat. Considering Sitaw water which is in the southern part of Mon coast both of hydrographic conditions and fisheries resource information are not available except a few information at Asin, Daminseik and Zeephyuthaung in Ye River Mouth areas. As for crustacean larvae composition and abundance, decapod larvae were highest abundance $\left(841 / \mathrm{m}^{3}\right)$ followed by mysis protozoea $\left(744 / \mathrm{m}^{3}\right)$ and stomatopod larvae $\left(719 / \mathrm{m}^{3}\right)$. The diversity of 8 orders group of crustacean larvae found 1.098 and 1.000 for species diversity $\left(\mathrm{H}^{\prime}\right), 0.999$ and 0.909 for species evenness $\left(\mathrm{J}^{\prime}\right)$, and 0.345 and 0.297 for species richness $\left(\mathrm{R}^{\prime}\right)$
This information indicated that Ahlyat, Setse and Sitaw coastal water were areas of high diversity of crustacean larvae in Mon coastal water. Based on the frequency of occurrence, among the 4941 larvae $/ \mathrm{m}^{3}$ in Mon coastal water, the percentages by the most frequent species were decapod larvae $(94.44 \%)$ followed by mysis protozoea $(77.78 \%)$ and stomatopod larvae $(66.67 \%)$, respectively. This study showed the frequency of occurrence of crustacean larvae suggesting the system appeared not to be stable.

In Ahlyat sampling area, the highest and lowest monthly abundance of crustacean larvae were $\left(344 / \mathrm{m}^{3}\right)$ in June and $\left(110 / \mathrm{m}^{3}\right)$ in December. The highest and lowest monthly abundance of crustacean larvae in Setse sampling area were $\left(345 / \mathrm{m}^{3}\right)$ in February and $\left(112 / \mathrm{m}^{3}\right)$ in October. The highest and lowest monthly abundance of crustacean larvae were $\left(445 / \mathrm{m}^{3}\right)$ and $\left(303 / \mathrm{m}^{3}\right)$ in August and June at Sitaw sampling area. During the study period of March 2017 to February 2018 , the crustacean biomass ranged between $2.466 \mathrm{ml} / \mathrm{m}^{3}$ (decapod larvae) and $1.253 \mathrm{ml} / \mathrm{m}^{3}$ (isopod larvae). This result suggested that crustacean larvae in Mon coastal water were widely distributed inshore pelagic water, implying that this area was very important for habitat of adult crustacea and their larvae.

Regarding to larval crustacean assemblage in Mon coastal water, based on a cluster analysis, it illustrated the patchy distribution of the majority of crustacean larvae because the stations appearing similarity in larval groups and their abundance tended to be located adjacent to each other. This may be, in some extents, underline the influence of currents because larval lives are generally carried to elsewhere by currents. Although, the relationships between environmental parameters and crustacean larvae abundance have not been analyzed statistically due to the small sample sizes in this study. Nevertheless, the similarity cluster indicated the presence of 1-3major groups based on larval number in species with roughly similar abundance and constructed with 3-5clades and 6leaves. The binary similarity coefficient analysis of Sorensen similarity index (Ss) values comparing species composition between sampling months were recorded and they ranged from 22 (minimum similarity at August, October and February) to 90 (maximum similarity at October and December) (Table 5). Classification of crustacean larval assemblage by Ahlyat, Setse and Sitaw stations using dendrogram was shown in figure 4A-C. Ahlyat coastal water included 3 similarity cluster groups and followed by Setse and Sitaw coastal water indicated 2 similarity cluster groups based on larval number in order groups with roughly similar abundance.

Like the tropical Asian waters, Myanmar water was influenced by monsoons as well as by the river runoff. Ahlyat area in the north, Setse area in the middle portion and Sitaw in the south of Mon coastal water were influenced by Thanlwin River and some other smaller rivers. Sitaw area was largely influenced by Ye River. These river systems carried huge quantities of nutrient-rich and freshwater mass along the coast during south-west monsoon. In addition, Mon coastal water seems to be a brackish water system by Gulf of Martaban region. This area is not only topographically different from the other brackish water areas in Myanmar but also hydrological richer and more suitable than those areas. These favourable conditions probably supported the distribution and abundance of crustacean larvae as shown in Tables 2, 3 and 4 . The richest in diversity of crustacean larvae in this area might due to the influence of nutrient-rich from large rivers that discharged nutrients into the north to south of study areas and also the gulf areas around the enclosing islands. This present study, the highest larval abundance in April (933 larvae $/ \mathrm{m}^{3}$ ) followed by June ( 886 larvae/ 
$\left.\mathrm{m}^{3}\right)$ and February $\left(878\right.$ larvae $\left./ \mathrm{m}^{3}\right)$. These results suggested that Mon coastal water was the important fishery potential area in Myanmar. However, further study focused on the relationships of crustacean larvae and oceanographic parameters in different monsoon systems are needed for more understanding of the whole picture of crustacean larvae composition and abundance in Myanmar.

\section{Conclusion}

Diversity of crustacean larvae were identify based on 8orders group of which 2larval orders represented economically important group. Decapod and mysis protozoea were much frequency of occurrence and the rest 6 larval groups were frequent occurrence in the study area. It was observed that not many crustacean larvae distributed widely in Mon coastal water whilst a large number frequently occurred. In addition, biomass and larval crustacean assemblage in each station were appeared similarity in larval groups and their abundance tended to be located adjacent to each other. In overall, Sitaw appeared the richest diversity of crustacean larvae and also the highest average occurrence of crustacean larvae compared to Setse and Ahlyat.

\section{Acknowledgements}

I am indebted to Dr Aung Myat Kyaw Sein, Rector of Mawlamyine University and Dr Mie Mie Sein and Dr San San Aye, Pro-Rectors of Mawlamyine University, for their encouragement and supports in preparing this work. I am very grateful to Dr San Tha Tun, Professor and Head of the Department of Marine Science, Mawlamyine University, for his valuable suggestions and constructive criticisms on this study. I would like to express my sincere thanks to colleagues of Field Observation Group, Department of Marine Science, Mawlamyine University, for their kindly help me in many ways during field trip. Many thanks go to Daw Lwin Lwin, Retired Lecturer of the Department of Marine Science, Mawlamyine University, for her assistance in preparations of the manuscript. I would like to thank my beloved parents, U Win Maung and Daw Than Than Aye, for their physical, moral and financial supports throughout this study.

\section{Conflict of interest}

Author declares that there is no conflict of interest.

\section{References}

1 Azam F, Fenchel T, Field JG, et al. The ecological role of water-column microbes in the sea. Mar Ecol Prog Ser. 1983;10:257-263.

2 Sommer U, Sommer F. Cladocerans versus copepods the cause of contrasting top-down controls on freshwater and marine phytoplankton. Oecologia. 2006;147(2):183-194.

3 Becker BJ, Levin LA, Fodrie FJ, et al. Complex larval connectivity patterns among marine invertebrate populations. Proc Natl Acad Sci. 2007;104(9):3267-3272.

4 Cowen RK, Sponaugle S. Larval dispersal and marine population connectivity. Annual Review of Marine Science. 2007;1:443-466.

5 Kough AS, Paris CB, Butler IVMJ. Larval connectivity and the international management of fisheries. Plos one. 2013;8(6):e64970.

6 Jablonski D, Lutz RA. Larval ecology of marine benthic invertebrates: paleobiological implications. Biological Reviews. 1983;58(1):21-89.

7 Kyi Win. A study on the plankton from the pearl beds of Pearl Island (Pale Kyun). Paper presented at Burma Research Congress. 1969. (Unpublished; in Burmese).
8 Kyi Win, Soe Lwin, Maung Maung Twin, et al. A preliminary study on the plankton from Lampi Island. Paper presented at Burma Research Congress, 1970. (Unpublished; in Burmese).

9 Kyi Win, Myo Thant, Hla Hla Cho. A preliminary study on the plankton from Moskos Island. Paper presented at Burma Research Congress, 1971. (Unpublished; in Burmese).

10 Kyi Win, Han Shein, Thin Soe, et al. A preliminary study on the plankton from the coastal water of Mawtin Point and Diamond Island. Paper presented at Burma Research Congress, 1972. (Unpublished; in Burmese). 1972.

11 Kyi Win, Han Shein, Mang Maung Myint. Distribution of plankton from some parts of Arakan state coastal water. Paper presented at Burma Research Congress, 1975. (Unpublished; in Burmese). 1975.

12 Kyi Win. A species list of zooplankton from the coastal waters of Burma. Proc. Symp Warm Water Zoopl. Spl. Publ. UNESCO/NIO. 1977; pp. 93-99.

13 Kyi Win, Han Shein. A species list of zooplankton collected during the Oceanographic Expedition to the adjacent water of Cocos Island. Paper presented at Burma Research Congress, 1979. (Unpublished; in Burmese).

14 Kyi Win, Han Shein. On marine zooplankton utilized as food in Burma. Paper presented at Burma Research Congress. 1988. (Unpublished; in Burmese).

15 Saw Han Shein, Aung Myint, Maung Maung Myint. A preliminary study on the plankton from the neighbouring water of Gwa, Kyaukphyu and Sittwe. Paper presented at Burma Research Congress, 1973. (Unpublished; in Burmese).

16 Aung Kyi. Study of the morphology and abundancy of copepods from the mouth of Salween river estuary. Unpublished MSc Thesis, Department of zoology, Arts and Science University, Rangoon. 1976.

17 Gayder Kittim Ku. The systematics of some planktonic copepoda and their distribution during the pre and post-monsoon in the Gulf of Martaban. Unpublished MSc Thesis, Department of Zoology, Arts and Science University, Rangoon. 1979.

18 Maung Maung Myint. The seasonal fluctuations of some large copepod species off Setse. Unpublished MSc Thesis. Department of Marine Science. Mawlamyine University. 1986.

19 Htay Htay Mon. The seasonal variation of zooplankton species groups in the Mawlamyine River. Unpublished MSc Thesis. Department of Marine Science. Mawlamyine University. 1995.

20 Win Win Nwe. Spatial and depth-wise distribution of zooplankton groups in the north Andaman Sea during the pre-monsoon of 2002. Unpublished MRes Thesis. Department of Marine Science, Mawlamyine University. 2007.

21 Zin Lin Khine, Htay Aung. Distribution, abundance and diversity of plankton in Myanmar Territory waters of North East Andaman Sea. Jour Myan Acad Art \& Sc. 2009;7(5):389-414.

22 Htay Htay Mon. Study on the diversity and distribution of zooplankton in the Gulf of Martaban and its adjacent waters. Unpublished $\mathrm{PhD}$ Dissertation. Department of Marine Science, Mawlamyine University. 2009.

23 Aye Mi San. Study on the zooplankton of karoppi waters, Mon State. Unpublished MSc Thesis. Department of Marine Science, Mawlamyine University. 2010.

24 Nyo Nyo San. Note on some zooplankton in coastal waters of the Kalagauk Island, Mon State. Unpublished MSc Thesis. Department of Marine Science, Mawlamyine University. 2010.

25 Naung Naung Oo. Studies on the planktonic larvae in the Damin Tidal 
Creek of Setse. Unpublished MSc Thesis. Department of Marine Science, Mawlamyine University. 2011.

26 Aung Aung Htaik. Study on the zooplankton in Setse waters. Unpublished MRes Thesis. Department of Marine Science, Mawlamyine University. 2011.

27 Zin Lin Khine. Study on zooplankton populations in the water mass of the Taninthayi coast with emphasis on copepods. Unpublished $\mathrm{PhD}$ Dissertation. Department of Marine Science, Mawlamyine University. 2013.

28 Nyan Moe Naing. A study on the zooplankton in Ka Byar Wa coastal waters, Ye Township, Mon State. Unpublished MSc Thesis. Department of Marine Science, Mawlamyine University. 2014.

29 Saw Tin Shwe. A study on the zooplankton in Ye River Mouth, Mon State. Unpublished MSc Thesis. Department of Marine Science, Mawlamyine University. 2014

30 War War Nwe. Seasonal and spatial distribution of zooplankton from Taninthayi coastal waters. Unpublished PhD Dissertation. Department of Marine Science, Mawlamyine University. 2016.
31 Wickstead JH. An introduction to the study of tropical plankton. Hutchinson Tropical Monographs, Plymouth, London. 1965. 153 p.

32 Harris SA, Cyrus DP, Beckley LE. Horizontal trends in larval fish diversity and abundance along an ocean-estuarine gradient on the northern KwaZulu-Natal coast, South Africa. Estuarine, Coastal and Shelf Science. 2001;53(2):221-235.

33 Shannon CE, Wiener W. The mathematical theory of communication University of Illinoise. Urban press, Illinoise, USA; 1963. 117 p.

34 Pielou EC. Ecological diversity. John Wiley \& Sons, INC, USA. 1975. $165 \mathrm{p}$.

35 Margalef R. Perspectives in ecological theory. University of Chicago press, USA. 1968. $111 \mathrm{p}$

36 Sorensen T. A method for establishing groups of equal amplitude in plant sociology based on similarity of species content and its application to analyses of vegetation on Danish commons. Kong Dabish Vidensk Selsk Biol Skr Copenhagen. 1948;5:1-34. 